\title{
A Quantitative Assessment of Causes of Bovine Liver Condemnation and Its Implication for Food Security in the Eastern Cape Province South Africa
}

\author{
Ishmael Festus Jaja ${ }^{1, *}$, Borden Mushonga ${ }^{2}$, Ezekiel Green ${ }^{3,4}$ and Voster Muchenje ${ }^{1}$ \\ 1 Department of Livestock and Pasture Science, University of Fort Hare, Alice 5700, South Africa; \\ vmuchenje@ufh.ac.za \\ 2 School of Veterinary Medicine, Faculty of Agriculture and Natural Resources, University of Namibia, \\ 13301 Namibia, South Africa; bordenmushonga@gmail.com \\ 3 Department of Biochemistry and Microbiology, University of Fort Hare, Alice 5700, South Africa; \\ egreen@ufh.ac.za \\ 4 Department of Biotechnology and Food, Science, Faculty of Science, University of Johannesburg, \\ Doornfontein 2028, South Africa; egreen@uj.ac.za \\ * Correspondence: ijaja@ufh.ac.za; Tel.: +27-84-802-9111; Fax: +27-86-770-6869
}

Academic Editor: Iain Gordon

Received: 14 February 2017; Accepted: 29 April 2017; Published: 3 May 2017

\begin{abstract}
Food production needs to double, with minimum waste, if hunger and poverty is to be alleviated in South Africa. The condemnation of liver during meat inspection represents a huge waste of a protein food resource. This paper measures the quantity of liver condemned in three abattoirs in the Eastern Cape Province of South Africa and assesses the causes and the monetary loss associated with these condemnations. A retrospective study (RS) $(n=51302)$ involving the use of abattoir slaughter records from 2010-2012 and a post-mortem meat inspection (PMMI) $(n=1374)$ was conducted from July to December 2013. The RS revealed the leading cause of liver wastage as fasciolosis $(5.95 \%, 4.48 \%$, and $2.7 \%)$, fibrosis $(2.74 \%, 2.37 \%$, and $1.0 \%)$, and abscessation $(1.11 \%, 2.78 \%$, and 1.5\%) for the 2010, 2011, and 2012 respectively. During the PMMI, the same factors caused liver condemnation in addition to calcification $(8.3 \%, 6.8 \%$, and 3.2\%), Cysticercosis bovis $(1.7 \%, 2.4 \%$, and $1.3 \%$ ) and improper evisceration $(4.8 \%, 12.4 \%$, and $27.1 \%)$ for the abattoirs $\mathrm{X}, \mathrm{Y}$, and $\mathrm{Z}$ respectively. A total of R 343, 330 (USD 45,271.07) was lost due to the condemnation of liver between 2010 and 2012. The further loss of $3290.4 \mathrm{~kg}$ of liver was calculated for the six month in 2013 , and its financial value was R 59, 227.2 (USD 5889.82). The result of this study provide baseline information on major causes of liver wastage in cattle slaughtered in South Africa as well as the direct financial losses and demonstrate the huge waste of ideal protein food source.
\end{abstract}

Keywords: food waste; liver condemnation; abattoir; meat; Eastern Cape; fasciolosis

\section{Introduction}

The world population is currently estimated to be seven billion but is expected to rise to eight billion by 2030 and over nine billion by 2050 [1]. Africa's population is also estimated to double from one billion to two billion people by 2050. The production of sufficient amounts of high quality, affordable, and safe food requires the sustainable use of scarce agricultural resources with less waste. Notably, several biological and non-biological factors affect livestock production negatively, leading to post-slaughter losses. The impact of biological factors such as animal diseases far outweighs other factors because it increases livestock mortality as well as reducing the safety and quality of food supplies. 
Meat provides a rich source of animal protein and is an important staple food that is highly demanded in many parts of the world. Consumption of meat in South Africa is said to be $41 \mathrm{~kg}$ per capita per year and is second only to Ghana in Africa [2]. Meat plays a crucial role in human nutrition in South Africa. Many studies have alluded to the decline in food production even as population increases [3-5]. Alongside the decline in agricultural output is the issue of food wastages at abattoirs. The liver is basically condemned due to preventable lesions/diseases detected during routine post-mortem meat inspection. Other reasons for condemnation may be for the aesthetics value of the liver and faulty slaughter techniques [6-10]. For livestock productivity to be doubled and to help mitigate food insecurity, the reduction in food wastage, especially along the production line, is crucial.

Many studies [9,11-15] in different African countries have looked at liver condemnation and shown a high prevalence of preventable parasitic and bacterial zoonosis, demonstrating the lack of a proper herd health programme necessary for the promotion of animal health in the various farms where these animals are bred. Meat safety should begin when the animal is conceived and continue to the point of delivery to the slaughterhouse. Furthermore, strategic hygiene assessment and monitoring system through the entire processing and value chain will ensure the safety of meat for consumers [16-18].

Animal products, and meat in particular, can be a source of infection or food poisoning. Two main factors responsible for food poisoning by meat are (i) the presence of animal diseases transmissible to humans by meat consumption and (ii) the contamination of the carcass or meat with external agents such as physical, chemical, or biological agents [16,19-22]. Public health concerns regarding the safety of meat necessitate both antemortem (AMMI) and post-mortem meat inspection (PMMI) at abattoirs using the guidelines by the South Africa Meat Safety Act of 2000 [23,24]. The PMMI of the slaughtered carcass is designed to identify and take away from the food chain all carcasses/offal that present grossly identifiable abnormalities that might affect safety or wholesomeness of the meat product $[5,25]$.

The monitoring and surveillance of emerging infectious and zoonotic diseases in food animals should be an integral component of every food safety system. Although PMMI has been criticized for its limitations, there is evidence that substantiates the sensitivity of meat inspection for identifying specific diseases of humans and animal importance $[5,26,27]$. Meat inspection is a veritable tool in data gathering on notifiable diseases, zoonoses, and endemic production diseases. Furthermore, it can be used to monitor disease that may lead to monetary losses associated with meat condemnation and syndromic surveillance system for improved detection of disease outbreaks [5,28-31]. Identifying and quantifying the causes of liver condemnation is the first step in diseases surveillance aimed at preventing further liver losses at the abattoir. Condemnation of the liver represents a reduction in available food resources. Research and discussion on food security and safety are very timely. Hence, the aim of this study was to evaluate causes of liver condemnation and the financial loss of condemnation.

\section{Materials and Methods}

\subsection{Study Area}

The study was carried out in the Eastern Cape (EC) Province located in the southeast of South Africa. It is bordered on the north by the Free State and Lesotho, KwaZulu-Natal to the north-east, the Indian Ocean to its south and south-eastern borders, and Western and Northern Cape to the west [32]. EC is the second largest province in the country, stretching approximately $169,580 \mathrm{~km}^{2}$, i.e., $13.9 \%$ of the total land area of South Africa. It has a high population density estimated at 41 persons per square $\mathrm{km}$. About $63 \%$ of the province's population lives in rural areas [33]. It has the highest unemployment rate in the country, with the poverty index showing approximately $47 \%$ of households living well below the poverty line [32]. In 2006, the greater part of the populace in seven out of the nine provinces of South Africa was living below the upper-bound poverty line. The province with the highest poverty levels was Limpopo, where three-quarters (74.4\%) of its inhabitants were poor, followed closely by Eastern 
Cape $(69.5 \%)$ and KwaZulu-Natal (69.1\%). The poor were only in the minority in the two provinces of Western Cape (36.9\%) and Gauteng (32.4\%) [34]. The study was conducted at three abattoirs (X, Y, and Z) located in the Amathole District, Chris Hani District, and in the Buffalo City Metropolitan Municipality of the EC Province, respectively. Abattoir $X$ was included in the study because of its proximity and ease of access by communal farmers, while $\mathrm{Y}$ and $\mathrm{Z}$ was included in the study due to the high number of animal slaughter per year for local and export markets. The place receives approximately $480 \mathrm{~mm}$ of rainfall per year, mostly in the summer months and is averagely-situated 586-2371 meters above sea level, high enough to be occasionally covered in snow. The temperatures in the Eastern Cape during the period of study ranged from $18{ }^{\circ} \mathrm{C}$ to $39^{\circ} \mathrm{C}$ with mean temperatures of $20.5^{\circ} \mathrm{C}$. The 14 million cattle in South Africa are found in communal areas. Of this number, over 3.2 million resides in the EC Province [35]. The 2011 agricultural census show that $86 \%$ of the populace keep an average 1-10 cattle [36], hence the choice of the EC Province is ideal for this research.

\subsection{Research Animals}

Male and female animals of different ages were included in the retrospective study (RS), antemortem meat inspection (AMMI), and post-mortem meat inspection (PMMI) study. Where retrospective implies the study of abattoir record from 2010 to 2012, antemortem (AMMI) refers to the survey of cattle for signs of diseases prior to slaughter, and the PMMI means post-mortem meat inspection of slaughtered cattle. Young animals' use as veal was not included in the study as these were not expected to harbor diseases that could lead to meat condemnation at the abattoir. These animals were brought from the different locations in the Eastern Cape.

\subsection{Sample Size Determination and Sampling}

The sample size was calculated based on the formula given by [37] with $95 \%$ confidence interval, $50 \%$ expected prevalence, and $5 \%$ desired absolute precision. The sample size was determined to be 382 for the high throughput abattoirs ( $\mathrm{Y}$ and $\mathrm{Z}$ ) and 176 for low throughput abattoir $(\mathrm{X})$. The sizes were adjusted to 1146 and 229, respectively. This adjustment became necessary to increase statistical accuracy beyond the $5 \%$ desired absolute precision and to account for the large number of animals slaughtered at the abattoir during the years from which the secondary data was obtained. The number of cattle slaughtered in the three abattoirs varied, and the sample size was maximized proportionally to $X(229), Y(458)$, and Z (687).

Abattoir $X$ is classified as low throughput and statutorily can only slaughter between 2 and 20 cattle per day. A typical case sampling technique of purposeful sampling was used for sample collection at abattoir $X$ during the PMMI. This sampling method allowed the researchers to sample all cases of condemned liver at this abattoir [38]. This sampling method was used because of the small number of animal slaughtered in the low throughput abattoir, whereas a systematic random sampling was the best fit for $\mathrm{Y}$ and $\mathrm{Z}$ due to the high slaughter output per day [37]. Sampling units for $\mathrm{X}$ involved the selection of rejected meat/offal and recording case as per unit, while sampling units for $Y$ and $\mathrm{Z}$ were selected at equal intervals with the first animal being selected randomly. The total number of animals slaughtered during the preceding year (2012) was obtained from the abattoir records as 26,401 cattle corresponding to 520,4078 , and 21,803 for X, Y, and Z, respectively. The AMMI and PMMI were carried out for six months in 2013, and during this time the number of slaughtered animal was calculated to be 20,791 cattle, corresponding to 322,3788 , and 16,681 representing X, Y, and Z, respectively. Sampling interval was thus computed as the total number of animals slaughtered during the study period divided by the required sample size [13]. Therefore, the sampling intervals for the $\mathrm{Y}$ was $8(3788 / 458)$ and for $\mathrm{Z}$ was $24(16,681 / 687)$. The first cattle were chosen randomly from the first eight and 24 animals, respectively. Subsequently, every eight and 24 cattle were included in the sample during the slaughter operation. 


\subsection{Study Types}

A cross-sectional type of study was employed that involved the use of abattoir records (RS) from 2010 to 2012 and an AMMI/PMMI that was conducted from July to December 2013. Slaughter information of 51,302 cattle was obtained from this record. The AMMI and PMMI were done in conjunction with authorized meat inspectors at the various abattoirs to document the causes of meat/offal condemnation. The direct financial loss was estimated using the average liver weight of five different breeds and multiplying the average weight with the market price of liver in 2010 to 2013.

The AMMI and PMMI were done following the procedure specified by the South African Meat Safety Act of 2000 [23]. Briefly, the animals were inspected for the presence of diseases at the lairage and data regarded animal age, sex, breed, body condition score, and distance travelled from farm to abattoir were recorded to assess the possible risk factors. Cattle ageing was done according to the method described by the US Department of Agriculture, Food Safety Inspection Service [39,40], and body condition score (BCS) was carried out using the method described the by the University of Georgia, Cooperative Extension services [41]. The BCS was classified into four categories including thin (1-3), borderline (4), optimum (5-7), and fat (8-9) on a 1-9 scale. For ease of data analysis, these categories were merged into three groups namely, poor (1-4), moderate (5-7), and good (8-9). Cattle breeds were identified using phenotypic appearance, and further information regarding the breed was obtained from the abattoir. Cattle included in the AMMI inspection were thoroughly screened for disease lesions, sick and anorexic animals were detained for further investigation, and healthy animals were passed for slaughter. During the PMMI, organs showing gross abnormality were separated, classified, and recorded in line with the guidelines for meat inspection in developing countries and the South African Meat Safety Act of 2000 [23,42].

The PMMI was performed after the slaughter of the cattle using liver palpation and visual examination. The meat inspectors systematically cut at various suspicious and disease focal point to ascertain the health and aesthetic of the liver. Organs/offal with diseases and lesions were grossly detected based on pathological changes, i.e., size, colour, the presence of lesions or parasites, morphology, and consistency. Bovine livers suspected of Cysticercosis were detained for further confirmation by the veterinary personnel in charge of the abattoir. Other condemned organs upon slaughter were passed through a condemn chamber to the condemnation room where they were treated and disposed of. Livers classified as totally condemned were rejected and destroyed to avoid human consumption. In cases of partial condemnation, the liver was trimmed and the weight of the trimmed part taken. The comdemned liver was collected into a measuring drum and weighed using an Ansutek M1/M2 Portable Crane Scale (Ansutek Commercial Ltd., Manukau, New Zealand). The weight of the condemnation drum subtracted to get the accurate kilogram weight of condemned organ. The record of partial condemnation was taken on the days the abattoirs were visited during the six months of the research, and the monetary loss was calculated based on current market price per kilogram of the liver in 2013.

\subsection{Direct Financial Loss}

The average weight of liver was taken and the measurement recorded as $5.8 \pm 2.39$ Standard deviation $(\mathrm{kg} \pm \mathrm{SD})$, while the price for liver was obtained from the three abattoirs, and the calculated average was R 65 for whole liver and R 18 for $1 \mathrm{~kg}$ liver respectively. Monetary losses were calculated based on the average market price of the whole liver (in $\mathrm{kg}$ ) at the time of the study, while the prices for trimmed liver was estimated based on the price per kilogram of liver using the South African Rand (R). The average annual exchange rate of 1 South African Rand to 7.3, 7.21, and 8.17 United State Dollar (USD) for 2010, 2011, and 2012, respectively, was used for estimating the financial loss associated with liver condemnation. The average exchange rate for the three years was 7.56 USD. Financial losses associated with meat condemnation were in the form of losses due to whole or partial liver condemnation. 


\subsection{Data Analysis}

Data extracted from RS, AMMI, and PMMI were entered into a Microsoft Excel ${ }^{\circledR}$ (MS Excel 2007) spreadsheet. Liver condemnation rates were determined using simple descriptive statistics. The condemnation rate for RS was defined as the proportion of liver condemned to the total number of the carcass slaughtered in a year. The rate of condemnation for PMMI was calculated as the proportion of liver condemned to the total number of liver examined during the six-month PMMI study [13,43]. Monetary loss was calculated using average abattoir market price of the liver at the time of the study.

\section{Results}

\section{Reasons for Liver Condemnation and Associated Economic Loss}

The Retrospective Study (RS) revealed the leading cause of liver condemnation of the total number of animals slaughtered as fasciolosis (5.95\%), fibrosis (2.74\%), and hepatitis (1.44\%) in 2010. In 2011, fasciolosis $(4.48 \%)$, abscess $(2.78 \%)$, and fibrosis $(2.37 \%)$ were the main reasons for liver rejection at the abattoir. In 2012, livers were condemned mostly due to fasciolosis (2.7\%), abscess (1.5\%), and hepatitis (1.2\%). Melanosis, telangiectasis, and cysts were other causes of liver rejection in the three abattoirs studied (Table 1). The nature and type of cysts were not disclosed nor properly documented by the abattoir, hence it was not possible to ascribe the specific etiology of the cysts. Of the total inspected animals during the post-mortem meat inspection (PMMI), fasciolosis (13.1\%, $14.2 \%$, and $8.9 \%)$, improper evisceration $(4.8 \%, 12.4 \%$, and $27.1 \%)$, fibrosis $(1.7 \%, 10.5 \%$, and $9.2 \%)$ and abscess $(8.7 \%, 3.7 \%$, and $4.8 \%)$ were the leading causes of liver condemnation in the three abattoirs $\mathrm{X}, \mathrm{Y}$, and $\mathrm{Z}$, respectively (Table 2). Others causes of condemnation of public health importance were calcification $(8.3 \%, 6.8 \%$, and $3.2 \%)$ and Cysticercosis bovis $(1.7 \%, 2.4 \%$, and $1.3 \%)$ at abattoir $\mathrm{X}, \mathrm{Y}$, and $\mathrm{Z}$, respectively. The percentage loss for abattoir $X$ was $19.7 \%, 11.3 \%$, and $13.5 \%$ in the respective retrospective years, while abattoir $Y$ during the same period recorded percentage loss of $25.2 \%, 10.8 \%$, and $12.8 \%$. Abattoir $\mathrm{Z}$ recorded a decrease in percentage condemnation from $17.7 \%$ to $7.6 \%$ and $7.7 \%$ for the year 2010,2011 , and 2012, respectively (Table 1). A summarized monetary loss associated with liver condemnation for 2010 was R 89,245/USD 12,225.34, R 119,405/USD 16,561.03 in 2011, and R 134,680/USD 16,484.70 in 2012. The losses in RS were calculated for whole liver condemnation, whereas during the PMMI both whole liver and partial liver condemnations were recorded, necessitating the use of kg weight in the estimation of financial losses. The result from our estimation revealed a loss of R 59,227.2 (USD 5889.82) during the period in which the PMMI was conducted. 
Table 1. Causes of liver condemnation in cattle slaughtered from 2010 to 2012.

\begin{tabular}{|c|c|c|c|c|c|c|c|c|c|c|c|c|c|c|}
\hline \multirow[t]{4}{*}{ Organ Affected } & \multicolumn{4}{|c|}{ Causes of Condemnation } & \multicolumn{10}{|c|}{ Number (\%) of Condemned Organs during the Three Years $(n=51302)$} \\
\hline & \multicolumn{6}{|c|}{$2010(n=10276)$} & \multicolumn{2}{|c|}{$2011(n=14625)$} & \multicolumn{6}{|c|}{$2012(n=26,401)$} \\
\hline & \multicolumn{14}{|c|}{$(n=502)(n=2127)(n=7647)(n=437)(n=4414)(n=9774)(n=520)(n=4078)(n=21,803)$} \\
\hline & & $\mathrm{x}$ & Y & $\mathrm{Z}$ & Total (\%) & $\mathrm{X}$ & $\mathrm{Y}$ & $\mathbf{Z}$ & Total (\%) & $\mathbf{X}$ & Y & $\mathrm{Z}$ & Total (\%) & $\begin{array}{l}\text { Sum } \\
\text { Total }\end{array}$ \\
\hline \multirow{7}{*}{ Liver } & Abscess & 19 & 39 & 56 & $114(1.11)$ & 10 & 42 & 355 & $407(2.78)$ & 13 & 51 & 342 & $406(1.5)$ & 393 \\
\hline & Fasciolosis & 44 & 90 & 477 & 611 (5.95) & 63 & 281 & 311 & $655(4.48)$ & 36 & 187 & 484 & 707 (2.7) & 671 \\
\hline & Fibrosis & 8 & 41 & 232 & $281(2.74)$ & 13 & 45 & 288 & $346(2.37)$ & 9 & 32 & 225 & $266(1.0)$ & 257 \\
\hline & Hepatitis & 11 & 32 & 105 & 148 (1.44) & 12 & 41 & 130 & $183(1.25)$ & 20 & 19 & 266 & $305(1.2)$ & 285 \\
\hline & Cyst & 4 & 9 & 38 & $51(0.5)$ & 5 & 11 & 48 & $64(0.44)$ & 0 & 11 & 22 & $33(0.12)$ & 33 \\
\hline & Melanosis & 5 & 15 & 71 & $91(0.89)$ & 7 & 32 & 77 & $116(0.79)$ & 5 & 0 & 149 & $154(0.6)$ & 149 \\
\hline & Telangiectasis & 8 & 15 & 54 & 77 (0.75) & 0 & 25 & 41 & $66(0.45)$ & 9 & 10 & 182 & $201(0.8)$ & 192 \\
\hline Total & & 99 & 241 & 1033 & $1373(13)$ & 110 & 477 & 1250 & 1837 (13) & 92 & 310 & 1670 & $2072(8)$ & 1980 \\
\hline Loss in $R$ & & 6435 & 15,665 & 67,145 & 89,245 & 7150 & 31,005 & 81,250 & 119,405 & 5980 & 20,150 & 108,550 & 134,680 & 343,330 \\
\hline Loss in USD & & 881.51 & 2145.89 & 9197.95 & $12,225.34$ & 991.68 & 4300.28 & $11,269.07$ & $16,561.03$ & 731.95 & 2466.34 & $13,286.41$ & $16,484.70$ & $45,414.02$ \\
\hline $\begin{array}{c}\% \text { loss in } \\
\text { condemnation }\end{array}$ & & 19.7 & 11.3 & 13.5 & 13.4 & 25.2 & 10.8 & 12.8 & 12.6 & 17.7 & 7.6 & 7.7 & 9.5 & 10.2 \\
\hline
\end{tabular}

N/B: R means South African Rand, X means low through-put abattoir, Y and Z means high through-put abattoir.

Table 2. Conditions that led to the condemnation of liver $(X=229, Y=458$, and $Z=687)$ and associated monetary loss (R) during the post-mortem meat inspection (July to December 2013).

\begin{tabular}{|c|c|c|c|c|c|c|c|c|c|c|c|c|}
\hline \multirow[t]{2}{*}{ Causes of Condemnation } & \multicolumn{3}{|c|}{ Number Affected (Loss in \%) } & \multicolumn{3}{|c|}{ Loss in $\mathrm{Kg}$} & \multicolumn{5}{|c|}{ Monetary Loss $(R)$} & \multirow[b]{2}{*}{ Total (USD) } \\
\hline & $\mathrm{X}$ & $\mathbf{Y}$ & Z & $\mathrm{x}$ & $\mathbf{Y}$ & Z & $X$ & $\mathbf{Y}$ & Z & Total (kg) & Total (R) & \\
\hline Abscess & $20(8.7)$ & $17(3.7)$ & $33(4.8)$ & 63 & 78.6 & 171.4 & 1134 & 1414.8 & 3085.2 & 313 & 5634 & 560.27 \\
\hline Calcification & $19(8.3)$ & $31(6.8)$ & $22(3.2)$ & 72.2 & 119.8 & 97.6 & 1299.6 & 2156.4 & 1756.8 & 289.6 & 5212.8 & 518.38 \\
\hline Fasciolosis & 30 (13.1) & $65(14.2)$ & $61(8.9)$ & 114 & 217 & 253.8 & 2052 & 3906 & 4568.4 & 584.8 & 10526.4 & 1046.79 \\
\hline Fibrosis & $4(1.7)$ & 48 (10.5) & $63(9.2)$ & 12.2 & 208.4 & 215.4 & 219.6 & 3751.2 & 3877.2 & 436 & 7848 & 780.44 \\
\hline Hepatitis & $19(8.3)$ & $23(5)$ & $35(5.1)$ & 58.2 & 73.4 & 113 & 1047.6 & 1321.2 & 2034 & 244.6 & 4402.8 & 437.83 \\
\hline C. bovis & $4(1.7)$ & $11(2.4)$ & $9(1.3)$ & 23.2 & 60.8 & 42.2 & 417.6 & 1094.4 & 759.6 & 126.2 & 2271.6 & 225.90 \\
\hline Melanosis & $6(2.6)$ & $14(3.1)$ & $34(4.9)$ & 18.8 & 71.2 & 157.2 & 338.4 & 1281.6 & 2829.6 & 247.2 & 4449.6 & 442.49 \\
\hline Imp. Env. & $11(4.8)$ & 57 (12.4) & $186(27.1)$ & 33.8 & 130.6 & 778.5 & 608.4 & 2350.8 & 14013 & 942.9 & 16972.2 & 1687.79 \\
\hline Telangiectasis & $7(3.1)$ & $11(2.4)$ & $13(1.9)$ & 20.6 & 43.9 & 41.6 & 370.8 & 790.2 & 748.8 & 106.1 & 1909.8 & 189.92 \\
\hline Total & $120(52.4)$ & 277 (60.5) & $456(66.4)$ & 416 & 1003.7 & 1870.7 & 7488 & 18066.6 & 33672.6 & 3290.4 & 59227.2 & 5889.82 \\
\hline
\end{tabular}

Imp. Env means improper evisceration, C. bovis means Cysticercus bovis. R means South African Rand, X means low through-put abattoir, Y and Z means high through-put abattoir. 


\section{Discussions}

Abattoir meat inspection and slaughter records contribute to disease surveillance and control [44]. Meat inspection assists in monitoring diseases in the national herd and flock by providing database information to the veterinary department to control or eradicate diseases, produce wholesome products, and protect the public from zoonotic hazards $[13,25,45]$. Information obtained from such inspection can reveal causes of meat condemnation even in apparently healthy animals, and as such can be communicated back to the farmer to improve farm management and husbandry.

\subsection{Factor Responsible for Bovine Liver Condemnations}

Despite it small size, the highest relative losses (19.7\%, 25.2\%, and 17.7\%) of liver from 2010 to 2012 was at the low throughput abattoir $(X)$ contrary to the $11.3 \%, 10.8$, and $7.6 \%$ and $13.5,12.8 \%$, and $7.7 \%$ losses recorded at the high throughput abattoirs ( $Y$ and Z) (Table 1). The proximity of abattoir $X$ to rural/smallholder farmers encourages patronage by them. Therefore, it was presumed that the high level of condemnation was a direct result of poor animal management. Farming in rural communities is characterized by low input and poor animal husbandry. Many farmers in these communities lack access to veterinary inputs necessary for the enhancement of livestock productivity [46].

The leading cause of liver rejection at the abattoirs was fasciolosis, and a significant proportion of the liver was condemned either due to the presence of a cyst, Cysticercosis bovis, or calcification (Tables 1 and 2). A number of factors could be responsible for the level of condemnation recorded in this study including, the presence of parasite (F. hepatica, F. gigantica, C. bovis, and T. saginata), changes in seasonal rainfall pattern, or animal ingesting metacercaria through ingestion of raw contaminated aquatic plants or drinking contaminated stagnant water or effluent from sewage treatment plant [47-51]. The presence of various Fasciola spp. in the EC Province has been previously reported, and the lack of adequate rainfall further encourages stagnant streams and rivers that harbour these parasites. The unsupervised irrigation fields often flooded with water promotes the proliferation of the infectious larval stages of the parasite. There are several studies $[11,30,52]$ that support the findings of this study, others $[9,53,54]$ reported a higher rate of condemnation due to fasciolosis.

The prevalence of cysticercosis reported in this study may be low, but the consequence of its zoonotic potential should not be ignored. The use of guard dogs for control and regulation of livestock movement in the rural communities may play a role in the observe prevalence. Dogs are the definitive host for Echinococcus granulosus and can disseminate and contaminate the environment with the parasite, leading to disease transmission to ruminants and humans $[15,55]$. Furthermore, the high rate of cysticercosis in developing countries is often associated with poor sanitary infrastructure, lack of public knowledge of the condition, and indiscriminate disposal of sewage [56].

Fasciolosis and cysticercosis are important parasitic zoonosis of both veterinary and public health concerns. Even though humans are the accidental host, 2.4 million people in 61 countries are infected annually with Fasciola spp., and about 180 million are at risk of infection. A significant percentage of human fasciolosis occur in Africa, while production losses due to the livestock industry are estimated over USD 2 billion $[20,57,58]$. Furthermore, infection with Fasciola is associated with decrease milk, meat, and wool yield, and with financial loss associated with the cost of veterinary medication [59]. Severe damage to the bile duct and gall bladder of animals may lead death [60].

Human cases of cysticercosis appear to be most prevalent in the Eastern Cape Province of South Africa, particularly in the poor rural areas of Ciskei and Transkei, where pigs are allowed to move freely and sanitation facilities are scarce or nonexistent. In West Africa, studies have shown epilepsy to be associated with neurocysticercosis in human and further suggest that it is prevalent in low or middle-income endemic countries in which approximately $30 \%$ of epilepsy may be attributable to neurocysticercosis $[49,61,62]$. In animals, cysticercosis is associated with economic loss mainly due to condemnation, refrigeration, and downgrading of infected carcasses [63-66]. The high rate of condemnation of the liver points to the failure of proper animal health management techniques at the farm level. 
Liver abscessation, hepatitis, and fibrosis were responsible for a significant food waste during the RS and PMMI at the X, Y, and Z abattoirs for 2010, 2011, 2012, and 2013, respectively. An abscess is a localized collection of pus (dead neutrophils) separated from the surrounding tissue by a fibrous capsule formed following an infection. Grossly, it is an enlarged palpable lesion with fluctuating fluid. The most common pyogenic bacteria that causes abscesses in animals include Arcanobacterium (Actinomyces) pyogenes, Streptococcus spp., Staphylococcus spp., and Fusobacterium (Sphaerophorus) necrophorum [11]. Both liver abscesses and fibrosis are common complications of migratory actions of parasite larvae, which elicit inflammatory responses, progressing to a fibrotic or granulomatous formation of tissues along the biliary tract. Ultimately, the tissue reaction pre-optimizes the conditions necessary for secondary bacteria to flourish [26,67].

The common causes of hepatitis in animals include but are not limited to parasites such as Fasciola spp., Dicrocoelium dendriticum invasion and tunneling of the bile duct, and viruses and bacteria such as Hepatitis E virus, and Streptococcus spp. (S. agalactiae/dysgalactiae/pyogenes/zooepidemicus) [28]. The rate of condemnation due to hepatitis reported in this study may be related to the animal origin, as cattle from Fasciola infested areas are likely to increase the number of livers condemned for hepatitis. More so, animals from poorly resourced farmers lack adequate veterinary care and good husbandry $[44,46]$.

Several non-disease conditions such as melanosis, telangiectasis, and improper evisceration contributed considerably to liver rejection in this study. Although melanin is a natural pigment that occurs in the skin, hair nails and membranes, its abnormal accumulation in the liver causes dark pigmentation of the tissues leading to its condemnation. A report by Alton et al. [68] concurs with the $2.6-4.9 \%$ condemnation rate of the liver due to pigmentation obtained in this study.

Telangiectasis is a visible dark purple, red sunken area of the liver that may be caused by focal necrotizing hepatitis, fibrosis, metabolic disturbance, and hepatic abscesses [69,70]. In this study, the rejection of $3.1 \%, 2.4 \%$, and $1.9 \%$ liver at abattoirs $\mathrm{X}, \mathrm{Y}$, and $\mathrm{Z}$, respectively, due to telangiectasis was mainly because of the poor quality of its aesthetic value. Currently, abattoirs $Y$ and $Z$ export red meat to Europe, America, and Asia. There is a high demand for live animals as well as meat by consumers in these continents. For example, the value of red meat exports from South Africa has increased from R 791 million in 2013 to R 2.14 billion in 2016 [71]. Such export market may be influenced by the quality of meat produced especially from diseases. Disease and pathologic conditions affecting the aesthetic of organs designated for the export market either directly or indirectly cause the rejection of such organs by the importer countries due to zoonoses threat and aesthetic reasons. Import restriction could adversely affect South Africa's gross domestic product, the sustainable production of livestock, and farmers' livelihoods.

Improper eviscerations led to a high number of liver wastage $(4.8 \%, 12.4 \%$, and $27.1 \%)$ during the PMMI (Table 2). A study by Regassa et al. [13] revealed similar finding to what was obtained in the present study. Evisceration problems are commonly associated with poor slaughter process [70] and may lead to faecal contamination of organs with potentially infectious gut pathogens such as Salmonella and Shiga toxin-producing Escherichia coli [72]. In this study, evisceration problems were possibly due to untrained, inadequate and overburdened workers who usually rush to meet daily slaughter limits, hence the reduction in precision.

The EC Province is popular for livestock production, yet it is among the poorest in the country [34]. Disease and non-disease factors described in this study impact negatively on food security, taking into account the high rate of fasciolosis and other conditions reported in this study, we assume that many preventable disease agents hamper livestock productivity. Disease, especially infectious disease, "is a main constraint of biologically efficient livestock production and both endemic and exotic disease results in mortality and morbidity and hence less food than should ideally be available in current farming systems" [19]. The critical role of primary animal health in the production of healthy meat capable of supplying the protein needs of the populace and sustaining human health cannot be overstated. Food security programmes aimed at the sustainable production of sufficient amounts of 
affordable, high quality, safe food required to support the health and wellbeing of human populations is attainable if farms and production units adhere rigorously to strict and appropriate herd health plan.

\subsection{Financial Loss Associated with Liver Condemnation}

Food waste in the form of condemnation of the liver impacts negatively on food security, economy, export and domestic market. A total of R 343,330 (USD 45271.07) was lost due to the condemnation of liver in 2010, 2011, and 2012. Further loss calculated from the PMMI was R 59,227.2 (USD 5889.82). These findings are consistent with those of Tembo et al. [73] in Dodoma, Tanzania, where USD 32,465.50 annual loss due to the condemnation of liver was reported. Furthermore, a high loss of USD 230,088 was reported by Yibar et al. [74] in Bursa Province, Turkey. Apart from the monetary loss reported in this study, the amount of liver thrown away could substantially resolve hunger and food insecurity in an impoverished province such as the Eastern Cape where these condemnations are taking place. Beef liver has a protein content of $26 \%$, and the average human protein requirement is $56 \mathrm{~g}$ per day [75]. The condemned liver of only three months would be enough to feed 45 adults humans for a year. These condemnation rates may be grossly underestimated due to differences in the skills and experience of meat inspectors, the speed of the slaughtering activity, the meat inspection facilities, and sampling technique. Furthermore, considering the limitations of the traditional visual appraisal method of meat inspection, cysticerci could easily be missed as most cases of cysticercosis are light infections [12,15].

Generally, some of the limitations encountered in this study included the use of only visual inspection for the detection of pathologic conditions; thus, only those liver with gross lesions were likely to be diagnosed. The abattoir records may also have been underestimated because of poor meat inspection and generally poor record keeping. Furthermore, the sampling technique used in abattoirs $\mathrm{Y}$ and $\mathrm{Z}$ may have excluded some animals with the pathologic liver. In spite of the limitations mentioned, the impact of this food waste on food security cannot be overemphasized. This study also shows the relevance of meat inspection and abattoir records in safeguarding public and animal health through preventive medicine and syndromic surveillance.

\section{Conclusions}

This study highlighted the causes of liver condemnation and monetary loss associated with it. Food wastages at any point in the production chain affect farmer income, the sustainability of agricultural enterprise, and the domestic and export markets with severe consequences for food security. The leading cause of liver condemnation was fasciolosis, abscessation, and hepatitis. Other conditions were the cysts, calcification, cysticercosis, melanosis, fibrosis, and improper evisceration. Despite the limitations of this study, when huge financial losses are taken into account, there is clear evidence of the failure of disease prevention strategies at the farm level. Adopting a sound herd health programme and disease preventative measures will mitigate the losses observed in the study. Continuous farmer education through adequate veterinary service is vital to understanding the risk factors of disease, and effective treatment regimens are needed for disease prevention and control. Good slaughtering practices need to be implemented at abattoirs to reduce liver wastage due to improper evisceration. The use of modern diagnostic tests such as histopathology, immunohistochemistry, parasite identification, bacterial culture, antimicrobial susceptibility testing, surveillance of anthelmintic resistance, and molecular techniques for parasites, viruses, bacteria, and fungi detection could significantly improve meat inspection and disease detection in an abattoir. Considering the high prevalence of fasciolosis lesions at the abattoirs and the high rate of liver wastage due to improper eviscerations, this study recommends further study into possible anthelminthic resistance and capacity building and work related fatigue among slaughterhouse employees.

Acknowledgments: The authors acknowledge the National Research Foundation (Centre of Excellence in Food Security Project 140702: Animal Product Safety), the Research and Technology Fund (NRF/RTF T321-post slaughter), and the Govan Mbeki Research and Development Centre for providing the funds for this research. 
Thanks to Mr. Manzi, the Department of Agriculture Forestry and Fisheries (DAFF), and the meat inspectors at the participating abattoirs.

Author Contributions: All authors conceived the project. Ishmael Festus Jaja was responsible for data collection, data analysis, and writing the manuscript. Borden Mushonga, Voster Muchenje, and Ezekiel Green were responsible for supervision, data analysis, interpretation, and editing the manuscript. All authors have read and approved the final version of the manuscript.

Conflicts of Interest: The authors declare no conflict of interest.

\section{References}

1. United Nations Population Division (UNPD) Our Growing Population. Available online: http://www.un. org/en/sections/issues-depth/population/index.html (accessed on 7 April 2017).

2. FAO (Food and Agriculture Organization of the United Nations). The State of Food and Agriculture; FAO: Rome, Italy, 2009.

3. DAFF (Department of Agriculture, Forestry and Fisheries). A Profile of the South African Mutton Market Value Chain; DAFF: Pretoria, South Africa, 2011.

4. Miewald, C.; Ostry, A.; Hodgson, S. Food safety at the small scale: The case of meat inspection regulations in British Columbia's rural and remote communities. J. Rural Stud. 2013, 32, 93-102. [CrossRef]

5. Thomas-Bachli, A.L.; Pearl, D.L.; Friendship, R.M.; Berke, O. Exploring relationships between whole carcass condemnation abattoir data, non-disease factors and disease outbreaks in swine herds in Ontario (2001-2007). BMC Res. Notes 2014, 7, 185. [CrossRef] [PubMed]

6. Gajadhar, A.A.; Scandrett, W.B.; Forbes, L.B. Overview of food- and water-borne zoonotic parasites at the farm level Toxoplasmosis. Rev. Sci. Tech. 2006, 25, 595-606. [CrossRef] [PubMed]

7. Scandrett, W.B.; Haines, D.M.; Parker, S.E.; Robinson, Y.; Forbes, L.B.; Brandt, J.; Geerts, S.; Dorny, P.; Gajadhar, A.A. Veterinary Parasitology Validation of an immunohistochemical assay for bovine cysticercosis, with comparison to a standard histological method. Vet. Parasitol. 2012, 186, 301-311. [CrossRef] [PubMed]

8. Van Wyk, I.C.; Boomker, J. Parasites of South African wildlife. XVIV. The prevalence of helminths in some common antelopes, warthogs and a bushpig in the Limpopo province, South Africa. Onderstepoort J. Vet. Res. 2011, 78, 1-11. [CrossRef] [PubMed]

9. Fekadu, A.; Legesse, E.; Tesfaye, D. The Cause, Rate and Economic Implication of Organ Condemnation of Cattle Slaughtered at Jimma Municipal Abattoir, Southwestern Ethiopia. Glob. Vet. 2012, 9, 396-400.

10. Dupuy, C.; Morlot, C.; Gilot-fromont, E.; Mas, M.; Grandmontagne, C.; Gilli-dunoyer, P.; Gay, E.; Callait-cardinal, M. Veterinary Parasitology Prevalence of Taenia saginata cysticercosis in French cattle in 2010. Vet. Parasitol. 2014, 203, 65-72. [CrossRef] [PubMed]

11. Mellau, L.S.B.; Nonga, H.E.; Karimuribo, E.D. A Slaughterhouse Survey of Liver Lesions in Slaughtered Cattle, Sheep and Goats at Arusha, Tanzania. Res. J. Vet. Sci. 2010, 3, 179-188. [CrossRef]

12. Phiri, A.M. Common conditions leading to cattle carcass and offal condemnations at 3 abattoirs in the Western Province of Zambia and their zoonotic implications to consumers. J. S. Afr. Vet. Assoc. 2006, 77, 28-32. [CrossRef] [PubMed]

13. Regassa, A.; Moje, N.; Megersa, B.; Beyene, D.; Sheferaw, D.; Debela, E.; Abunna, F.; Skjerve, E. Major causes of organs and carcass condemnation in small ruminants slaughtered at Luna Export Abattoir, Oromia Regional State, Ethiopia. Prev. Vet. Med. 2013, 110, 139-148. [CrossRef] [PubMed]

14. Pfukenyi, D.M.; Mukaratirwa, S. A retrospective study of the prevalence and seasonal variation of Fasciola gigantica in cattle slaughtered in the major abattoirs of Zimbabwe between 1990 and 1999. Onderstepoort J. Vet. Res. 2004, 71, 181-187. [CrossRef] [PubMed]

15. Jaja, I.F.; Mushonga, B.; Green, E.; Muchenje, V. Prevalence of lung lesions in slaughtered cattle in the Eastern Cape Province, South Africa. J. S. Afr. Vet. Assoc. 2014, 87, 1-9. [CrossRef] [PubMed]

16. Garcia Pinillos, R.; Jukes, D.J. Hygiene assessment system (HAS) scores-An analysis of the available data from English slaughterhouses. Food Control 2008, 19, 806-816. [CrossRef]

17. Poumeyrol, G.; Rosset, P.; Noel, V.; Morelli, E. HACCP methodology implementation of meat pate hazard analysis in pork butchery. Food Control 2010, 21, 1500-1506. [CrossRef]

18. Edwards, D.S.; Johnston, A.M.; Mead, G.C. Meat inspection: An overview of present practices and future trends. Vet. J. 1997, 154, 135-147. [CrossRef] 
19. Fitzpatrick, J.L. Global food security: The impact of veterinary parasites and parasitologists. Vet. Parasitol. 2013, 195, 233-248. [CrossRef] [PubMed]

20. Dorny, P.; Praet, N.; Deckers, N.; Gabriel, S. Emerging food-borne parasites. Vet. Parasitol. 2009, 163, $196-206$. [CrossRef] [PubMed]

21. Karabudak, E.; Bas, M.; Kiziltan, G. Food safety in the home consumption of meat in Turkey. Food Control 2008, 19, 320-327. [CrossRef]

22. Iwu, C.J.; Iweriebor, B.C.; Obi, L.C.; Okoh, A.I. Occurrence of non-O157 Shiga toxin-producing Escherichia coli in two commercial swine farms in the Eastern Cape Province, South Africa. Comp. Immunol. Microbiol. Infect. Dis. 2016, 44, 48-53. [CrossRef] [PubMed]

23. MSA Meat Safety Act (Act No. 40 of 2000). Government Gazette Notice No. 1106. Parliament of the Republic of South Africa; South African Meat Industry Company: Pretoria, South Africa, 2000.

24. Soji, Z.; Chikwanda, D.; Chikwanda, A.T.; Jaja, I.F.; Mushonga, B.; Muchenje, V. Relevance of the formal red meat classification system to the South African informal livestock sector. S. Afr. J. Anim. Sci. 2015, 45, 263-277.

25. Lupo, C.; Le Bouquin, S.; Allain, V.; Balaine, L.; Michel, V.; Petetin, I.; Colin, P.; Chauvin, C. Risk and indicators of condemnation of male turkey broilers in western France, February-July 2006. Prev. Vet. Med. 2010, 94, 240-250. [CrossRef] [PubMed]

26. Alton, G.D.; Pearl, D.L.; Bateman, K.G.; McNab, W.B.; Berke, O. Factors associated with whole carcass condemnation rates in provincially-inspected abattoirs in Ontario 2001-2007: Implications for food animal syndromic surveillance. BMC Vet. Res. 2010, 6, 42. [CrossRef] [PubMed]

27. Hill, A.A.; Horigan, V.; Clarke, K.A.; Dewé, T.C.M.; Stärk, K.D.C.; O’Brien, S.; Buncic, S. A qualitative risk assessment for visual-only post-mortem meat inspection of cattle, sheep, goats and farmed/wild deer. Food Control 2014, 38, 96-103. [CrossRef]

28. Blagojevic, B.; Antic, D. Assessment of potential contribution of official meat inspection and abattoir process hygiene to biological safety assurance of final beef and pork carcasses. Food Control 2014, 36, 174-182. [CrossRef]

29. Cadmus, S.I.B.; Adesokan, H.K. Causes and implications of bovine organs/offal condemnations in some abattoirs in Western Nigeria. Trop. Anim. Health Prod. 2009, 41, 1455-1463. [CrossRef] [PubMed]

30. Mellau, B.L.; Nonga, H.E.; Karimuribo, E.D. Slaughter stock abattoir survey of carcasses and organ/offal condemnations in Arusha region, northern Tanzania. Trop. Anim. Health Prod. 2011, 43, 857-864. [CrossRef] [PubMed]

31. Stärk, K.D.C.; Alonso, S.; Dadios, N.; Dupuy, C.; Ellerbroek, L.; Georgiev, M.; Hardstaff, J.; Huneau-Salaün, A.; Laugier, C.; Mateus, A.; et al. Strengths and weaknesses of meat inspection as a contribution to animal health and welfare surveillance. Food Control 2014, 39, 154-162. [CrossRef]

32. Bradshaw, D.; Groenewald, P.; Laubscher, R.; Nannan, N.; Nojilana, B.; Norman, R.; Pieterse, D.; Schneider, M.; Bourne, D.E.; Timaeus, I.M.; et al. Initial burden of disease estimates for South Africa, 2000. S. Afr. Med. J. 2003, 93, 682-688. [PubMed]

33. Bradshaw, D.; Nannan, N.; Groenewald, P.; Joubert, J.; Laubscher, R.; Nojilana, B.; Norman, R.; Pieterse, D.; Schneider, M. Provincial mortality in South Africa, 2000 priority setting for now and a benchmark for the future. S. Afr. Med. J. 2005, 95, 496-503. [PubMed]

34. Statistics South Africa. Poverty Trends in South Africa: An Examination of Absolute Poverty between 2006 and 2011; Statistics South Africa: Pretoria, South Africa, 2014.

35. Tada, O.; Muchenje, V.; Dzama, K. Effective population size and inbreeding rate of indigenous Nguni cattle under in situ conservation in the low-input communal production system. S. Afr. J. Anim. Sci. 2013, 43, 138-142. [CrossRef]

36. Lehohla, P. Census 2011 Agricultural Households Key Highlights; Report No. 03-11-01 (2011); Statistics South Africa: Pretoria, South Africa, 2013.

37. Thrusfield, M. Surveys In: Veterinary Epidemiology, 3rd ed.; Blackwell Science Ltd.: London, UK, 2005.

38. Teddlie, C.; Yu, F. Mixed Methods Sampling: A Typology With Examples. J. Mix. Methods Res. 2007, 1, 77-100. [CrossRef]

39. FSIS (Food Safety and Inspection Service). Using Dentition to Age Cattle. Available online: www.fsis.usda. gov/OFO/TSC/bse_information.htm (accessed on 15 February 2013). 
40. Torell, R.; Bruce, B.; Kvasnicka, B.; Conley, K. Methods of Determining Age in Cattle., Cattle Producer's Library: CL712. University of Nevada, Reno, NV. Available online: http:/ /www.unce.unr.edu/publications / files/ag/other/cl712.pdf (accessed on 4 July 2013).

41. National Research Council (NRC). Nutrient Requirements of Beef Cattle, 7th Revised ed.; NRC: Washington, DC, USA, 2000.

42. Herenda, D.; Chambers, P.G.; Ettriqui, A.; Seneviratnap, P.; DaSilvat, T.J.P. Manual on Meat Inspection for Developing Countries. FAO Animal Production and Health Paper 119; Food and Agriculture Organization of the United Nations: Rome, Italy, 1994.

43. Equar, Y.; Gashaw, A. Prevalence of Bovine Fasciolosis, Amplitude of Liver Condemnation and its Economic Impact in Slaughtered Cattle at Municipal Abattoir of Mekelle, North Ethiopia. Int. J. Curr. Agric. Res. 2012, 1, 10-14.

44. Komba, E.V.G.; Komba, E.V.; Mkupasi, E.M.; Mbyuzi, A.O.; Mshamu, S.; Mzula, A.; Luwumba, D. Sanitary practices and occurrence of zoonotic conditions in cattle at slaughter in Morogoro Municipality, Tanzania: Implications for public health. Tanzan J. Health Res. 2012, 14, 1-12. [CrossRef]

45. Van Llogtestijn, J.G. Integrated quality of meat safety. A New Approach. Meat Focus Int. 1993, 2, $123-128$.

46. Musemwa, L.; Mushunje, A.; Chimonyo, M.; Fraser, G.; Mapiye, C.; Muchenje, V. Nguni cattle marketing constraints and opportunities in the communal areas of South Africa: Review. Afr. J. Agric. Res. Vol. 2008, 3, 239-245.

47. Calvo-artavia, F.F.; Nielsen, L.R.; Dahl, J.; Clausen, D.M.; Alban, L. Occurrence and factors associated with bovine cysticercosis recorded in cattle at meat inspection in Denmark in 2004-2011. Prev. Vet. Med. 2013, 110, 177-182. [CrossRef] [PubMed]

48. Nithiuthai, S.; Anantaphruti, M.T.; Waikagul, J.; Gajadhar, A. Waterborne zoonotic helminthiases. Vet. Parasitol. 2004, 126, 167-193. [CrossRef] [PubMed]

49. Torgerson, P.R.; Macpherson, C.N.L. The socioeconomic burden of parasitic zoonoses: Global trends. Vet. Parasitol. 2011, 182, 79-95. [CrossRef] [PubMed]

50. Phiri, A.M.; Phiri, I.K.; Sikasunge, C.S.; Monrad, J. Short Communication Prevalence of Fasciolosis in Zambian Cattle Observed at Selected Abattoirs with Emphasis on Age, Sex and Origin. J. Vet. Med. 2005, 416, 414-416. [CrossRef] [PubMed]

51. Mas-Coma, S.; Funatsu, I.R.; Bargues, M.D. Fasciola hepatica and lymnaeld snails occurring at very high altitude in South America. Parasitology 2001, 123, S115-S127. [CrossRef] [PubMed]

52. Mwabonimana, M.F.; Kassuku, A.A.; Ngowi, H.A.; Mellau, L.S.B.; Nonga, H.E.; Karimuribo, E.D. Prevalence and economic significance of bovine fasciolosis in slaughtered cattle at Arusha abattoir, Tanzania. Tanzan. Vet. J. 2010, 26, 60-77.

53. Bekele, M.; Tesfay, H.; Getachew, Y. Bovine Fasciolosis: Prevalence and its economic loss due to liver condemnation at Adwa Municipal Abattoir, North Ethiopia. Ejast 2010, 1, 39-47.

54. Mohammed, N.; Hailemariam, Z.; Mindaye, S.; Dewa, D. Major Cause of Liver Condemnation and Associated Financial Loss at Kombolcha Elfora Abattoir, South Wollo, Ethiopia. Eur. J. Appl. Sci. 2012, 4, 140-145.

55. Ernest, E.; Nonga, H.E.; Kassuku, A.A.; Kazwala, R.R. Hydatidosis of slaughtered animals in Ngorongoro district of Arusha region, Tanzania. Trop. Anim. Health Prod. 2009, 41, 1179-1185. [CrossRef] [PubMed]

56. Tolosa, T.; Tigre, W.; Teka, G.; Dorny, P. Prevalence of bovine cysticercosis and hydatidosis in Jimma municipal abattoir, South West Ethiopia. Onderstepoort J. Vet. Res. 2009, 76, 323-326. [CrossRef] [PubMed]

57. Khanjari, A.; Bahonar, A.; Fallah, S.; Bagheri, M.; Alizadeh, A.; Fallah, M.; Khanjari, Z. Prevalence of fasciolosis and dicrocoeliosis in slaughtered sheep and goats in Amol Abattoir, Mazandaran, Northern Iran. Asian Pac. J. Trop. Dis. 2014, 4, 120-124. [CrossRef]

58. Radfar, M.H.; Nourollahi-Fard, S.R.; Mohammadyari, N. Bovine fasciolosis: Prevalence, relationship between faecal egg count and worm burden and its economic impact due to liver condemnation at Rudsar abattoir, Northern Iran. J. Parasit. Dis. 2013, 1, 43-59. [CrossRef] [PubMed]

59. Tsegaye, E.; Mulugeta, B.S.; Begna, F. Prevalence of Bovine Fasciolosis and its Economic Significance in and Around Assela, Ethiopia Shiferaw Mulugeta, Feyisa Begna, Ephrem Tsegaye. Glob. J. Med. Res. 2011, 11, 5-13.

60. Degheidy, N.S.; Al-malki, J.S. Epidemiological Studies of Fasciolosis in Human and Animals at Taif, Saudi Arabia. World Appl. Sci. J. 2012, 19, 1099-1104. 
61. Carabin, H.; Krecek, R.C.; Cowan, L.D.; Michael, L.; Foyaca-Sibat, H.; Nash, T.; Willingham, A.L. Estimation of the cost of Taenia solium cysticercosis in Eastern Cape Province, South Africa. Trop. Med. Int. Health 2006, 11, 906-916. [CrossRef] [PubMed]

62. Phiri, I.K.; Ngowi, H.; Afonso, S.; Matenga, E.; Boa, M.; Mukaratirwa, S.; Githigia, S.; Saimo, M.; Sikasunge, C.; Maingi, N.; et al. The emergence of Taenia solium cysticercosis in Eastern and Southern Africa as a serious agricultural problem and public health risk. Acta Trop. 2003, 87, 13-23. [CrossRef]

63. Kumar, A.; Tadesse, G. Bovine cysticercosis in Ethiopia: A review Prevalence of bovine cysticercosis in Ethiopia. Ethiop. Vet. J. 2011, 15, 15-35. [CrossRef]

64. Megersa, B.; Tesfaye, E.; Regassa, A.; Abebe, R.; Abunna, F. Bovine cysticercosis in Cattle Slaughtered at Jimma Municipal Abattoir, South western Ethiopia: Prevalence, Cyst viability and Its Socio-economic importance. Vet. World 2010, 2, 257. [CrossRef]

65. Asaava, L.L.; Kitala, P.M.; Gathura, P.B.; Nanyingi, M.O.; Muchemi, G.; Schelling, E. A survey of bovine cysticercosis/human taeniosis in Northern Turkana. Prev. Vet. Med. 2009, 89, 197-204. [CrossRef] [PubMed]

66. Khaniki, G.R.J.; Raei, M.; Kia, E.B.; Haghi, A.M.; Selseleh, M. Prevalence of bovine cysticercosis in slaughtered cattle in Iran. Trop. Anim. Health Prod. 2010, 42, 141-143. [CrossRef] [PubMed]

67. Ahmedullah, F.; Akbor, M.; Haider, M.G.; Hossain, M.M.; Khan, M.A.H.N.A.; Hossain, M.I.; Shanta, I.S. Pathological Investigation of Liver of the Slaughtered Buffaloes in Barisal District. Bangl. J. Vet. Med. 2007, 5, 81-85. [CrossRef]

68. Alton, G.D.; Pearl, D.L.; Bateman, K.G.; McNab, W.B.; Berke, O. Suitability of bovine portion condemnations at provincially-inspected abattoirs in Ontario Canada for food animal syndromic surveillance. BMC Vet. Res. 2012, 8, 88. [CrossRef] [PubMed]

69. Atasever, A. Incidence and Pathologic Studies on Liver Telangiectasis in Beef Cattle. Turk. J. Vet. Anim. Sci. 2002, 26, 235-238.

70. Dupuy, C.; Morignat, E.; Maugey, X.; Vinard, J.-L.; Hendrikx, P.; Ducrot, C.; Calavas, D.; Gay, E. Defining syndromes using cattle meat inspection data for syndromic surveillance purposes: A statistical approach with the 2005-2010 data from ten French slaughterhouses. BMC Vet. Res. 2013, 9, 88. [CrossRef] [PubMed]

71. AgriPortal. Red Meat Exports bring SA R2bn South Africa; Agri Portal: Pretoria, South Africa, 2016; p. 4.

72. Iwu, C.J.; Iweriebor, B.C.; Obi, L.C.; Basson, A.K.; Okoh, A.I. Multidrug-Resistant Salmonella Isolates from Swine in the Eastern Cape Province, South Africa. J. Food Prot. 2016, 79, 1234-1239. [CrossRef] [PubMed]

73. Tembo, W.; Nonga, H.E. A survey of the causes of cattle organs and/or carcass condemnation, financial losses and magnitude of foetal wastage at an abattoir in Dodoma, Tanzania. Onderstepoort J. Vet. Res. 2015, 82, 855. [CrossRef] [PubMed]

74. Yibar, A.; Selcuk, O.; Senlik, B. Major causes of organ/carcass condemnation and financial loss estimation in animals slaughtered at two abattoirs in Bursa Province, Turkey. Prev. Vet. Med. 2015, 118, 28-35. [CrossRef] [PubMed]

75. Habarugira, G.; Mbasinga, G.; Mushonga, B.; Chitura, T.; Kandiwa, E.; Ojok, L. Pathological findings of condemned bovine liver specimens and associated economic loss at Nyabugogo abattoir, Kigali, Rwanda. Acta Trop. 2016, 164, 27-32. [CrossRef] [PubMed]

(C) 2017 by the authors. Licensee MDPI, Basel, Switzerland. This article is an open access article distributed under the terms and conditions of the Creative Commons Attribution (CC BY) license (http:/ / creativecommons.org/licenses/by/4.0/). 